\title{
International Space Station Environmental Control and Life Support System - Verification for the Pressurized Mating Adapters
}

\author{
David E. Williams \\ NASA, Johnson Space Center
}

Copyright @ 2007 SAE International

\begin{abstract}
The International Space Station (ISS) Pressurized Mating Adapters (PMAs) Environmental Control and Life Support (ECLS) System is comprised of three subsystems: Atmosphere Control and Supply (ACS), Temperature and Humidity Control (THC), and Water Recovery and Management (WRM). PMA 1 and PMA 2 flew to ISS on Flight 2A and PMA 3 flew to ISS on Flight 3A. This paper provides a summary of the PMAs ECLS design and the detailed Element Verification methodologies utilized during the Qualification phase for the PMAs.
\end{abstract}

\section{INTRODUCTION}

The PMAs were designed and built in two different configurations. PMA 2 and 3 have a Russian provided Androgynous Peripheral Attachment System (APAS) with a hatch on the side that the Shuttle docks to. This allows the Space Shuttle to dock to ISS using the Shuttle/MIR developed Orbiter Docking System (ODS). The APAS hatch on PMA 2/3 allows a docking target to be attached to the front of PMA 2/3 to help facilitate docking of the Space Shuttle to ISS and it provides a barrier to keep external contamination out of the interior part of the PMA when a Shuttle is not docked to ISS. On the other side of the PMA is a Common Berthing Mechanism (CBM) to attach PMA 2/3 to the different ISS Modules, as required during Assembly and as shown in Figure 1. The key PMA 2/3 ECLS design feature is to support scavenging and transferring excess Space Shuttle consumables to ISS and to provide ventilation within the PMA and between the Space Shuttle and ISS. The major difference between PMA 1 and PMA 2/3 is that PMA 1 does not have a hatch on its APAS and it does not have the hardware for scavenging and transferring consumables from the Space Shuttle to ISS. The hatch was removed from PMA 1 for structural reasons. The ISS Program made a decision early on to keep the PMA shell design the same by trading the hatch for the additional mass of two Node Control Software Multi-
plexer/Demultiplexers (MDMs) with heat pipes on the external part of PMA 1. The MDMs provides command and control of the ISS ECLS hardware in Node 1. PMA 1 also has the advantage that it did not have to be designed for interfacing with multiple ISS modules. It only supports the mating of Node 1 to the Functional Cargo Block (FGB).

The Verification of the ISS hardware is accomplished using a building block process. Verification starts at the Component Level and progresses until the Element Level Verification is complete. The primary objective of the Qualification Verification program is to ensure that the subsystems meet the section three requirements in the Prime Item Development Specifications (PIDS). The PIDS dictates whether a section three requirement is verified by test, analysis, inspection, and/or demonstration, as documented in section four of the PIDS.

The PMAs are a Protoflight Test Article since no Element Qualification Test Article exists. Therefore, no additional ground testing or evaluations can be performed on the PMAs after they had been installed in the Space Shuttle Payload Bay and launched to ISS. The ISS Program also made a decision early on to use engineering judgment and the normal preflight analysis that is done at launch minus one month ( $L-1$ mo.) instead of performing any special PMA 2 to Node 1 ECLS THC Verification activities for the $2 A$ series of Flights (i.e., Flights 2A, 2A.1, 2A.2a, and 2A.b) in support of Early Ingress into ISS. The PMAs are shown in Figure 4 during different stages of processing at Kennedy Space Center (KSC).

\section{SUBSYSTEM OVERVIEWS}

The PMA ECLS is comprised of three subsystems: THC, ACS, and WRM. This section will provide a general overview of these subsystems for the two different PMA configurations. 


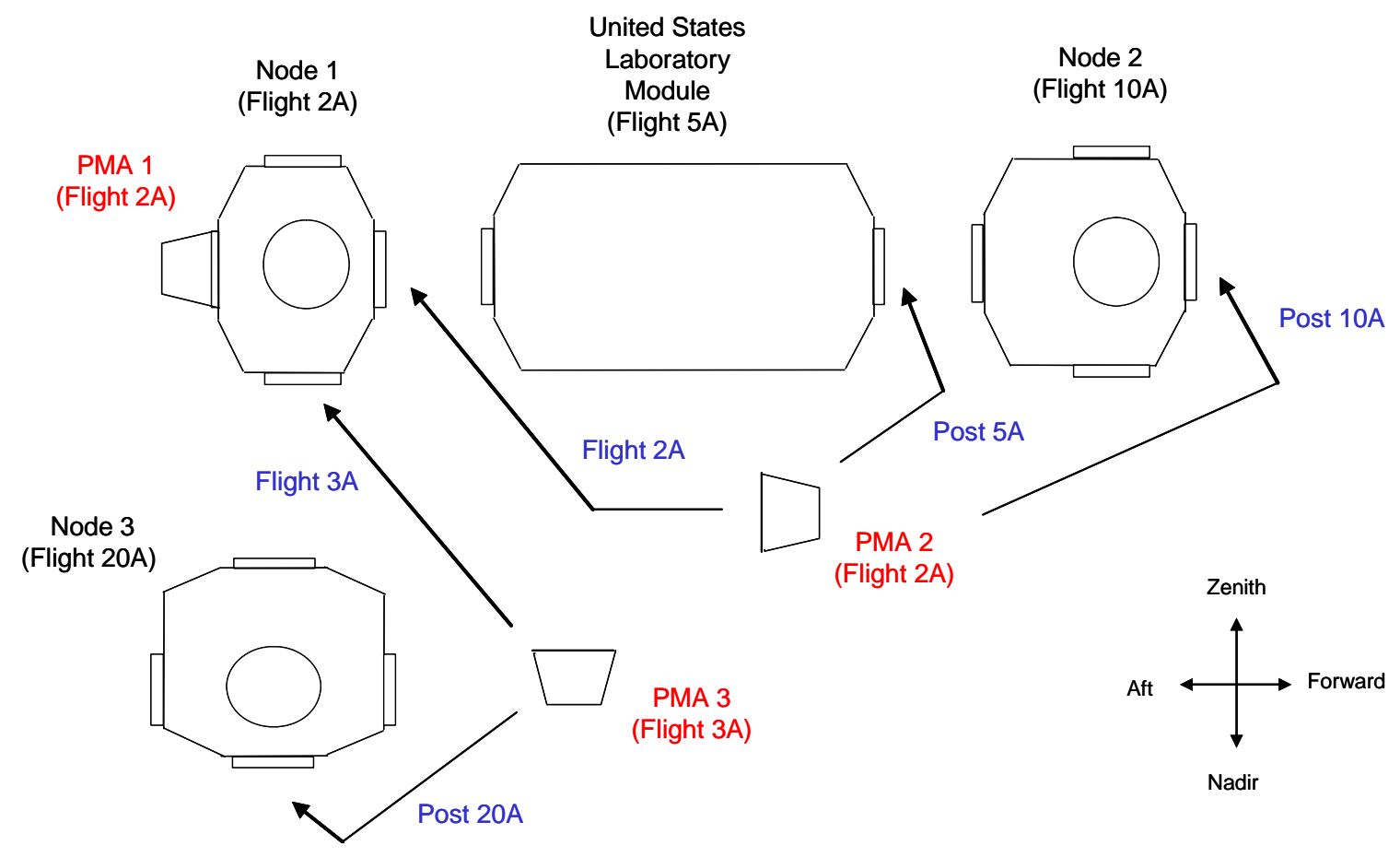

Figure 1 - Active Pressurized Mating Adapter Docking Locations

\section{PMA 1 THC:}

The purpose of the PMA 1 THC subsystem is to transfer Intermodule Ventilation (IMV) air from the Russian Segment (RS) to Node 1 via an air duct assembly, as shown in Figure 2. The PMA 1 air duct assembly consists of four parts: a rigid duct, a flexible duct, V-band clamps, and an air register that can be manually opened or closed by the crew. The air is returned from Node 1 to the RS through the PMA 1 cabin and then through the PMA 1 APAS hatch opening.

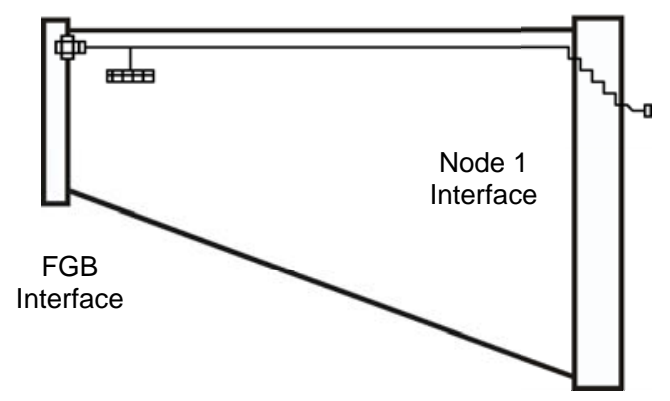

Figure 2 - PMA 1 THC Schematic

\section{PMA 2/3 THC:}

The purpose of the PMA 2/3 THC subsystem is to transfer IMV air from the Space Shuttle to the attached
ISS module via an air duct assembly, as shown in Figure 3. The PMA 2/3 air duct assembly consists of four parts: a rigid duct, a flexible duct, V-band clamps, and an air register that can be manually opened or closed by the crew. The air is returned from the attached ISS module to the Space Shuttle through the open PMA 2/3 cabin and then through the PMA 2/3 APAS hatch opening when the hatch is open. The major difference between the PMA 2/3 and the PMA 1 air duct assembly is that the PMA 2/3 ducting at the Space Shuttle interface has a flange attached to it that reduces the duct diameter since the Space Shuttle flexible ODS air transfer duct is a smaller diameter than the normal ISS flexible ducts. The other difference is that at the ISS module end of the flexible duct there is a small miter offset duct to compensate for interference between the duct and the

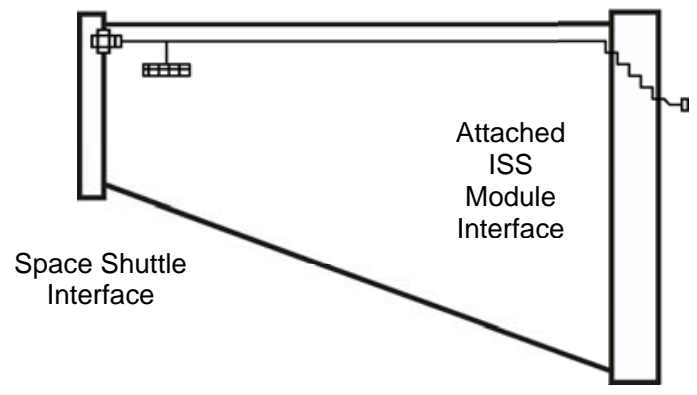

Figure 3 - PMA 2/3 THC Schematic 


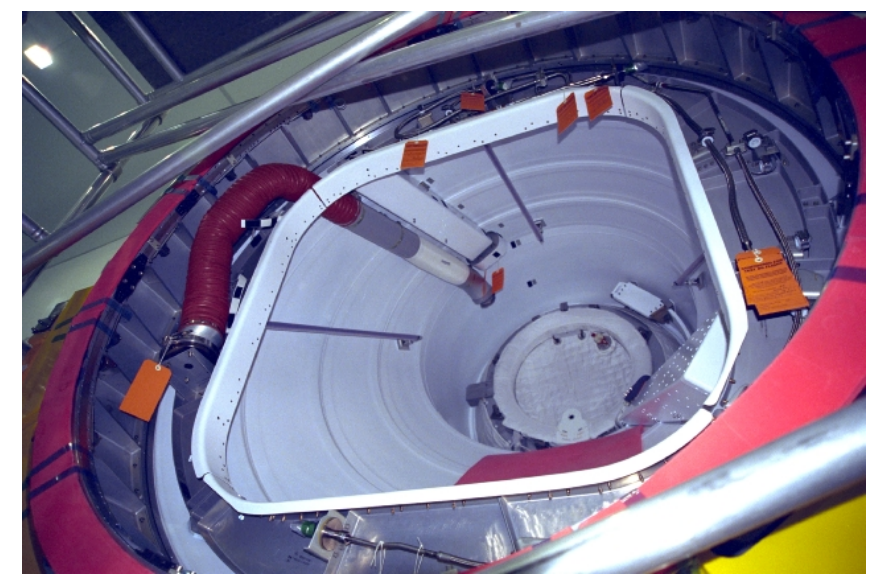

Inside PMA 3

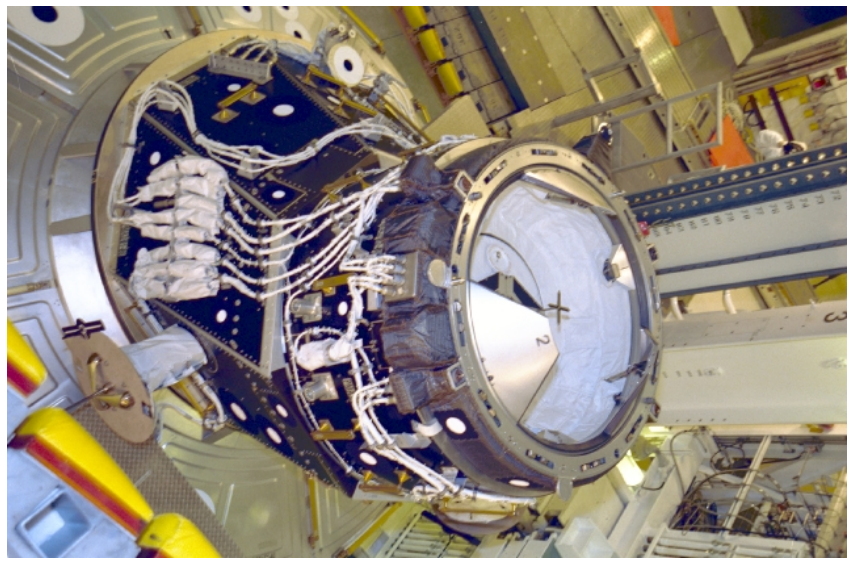

PMA 2 Attached to Node 1

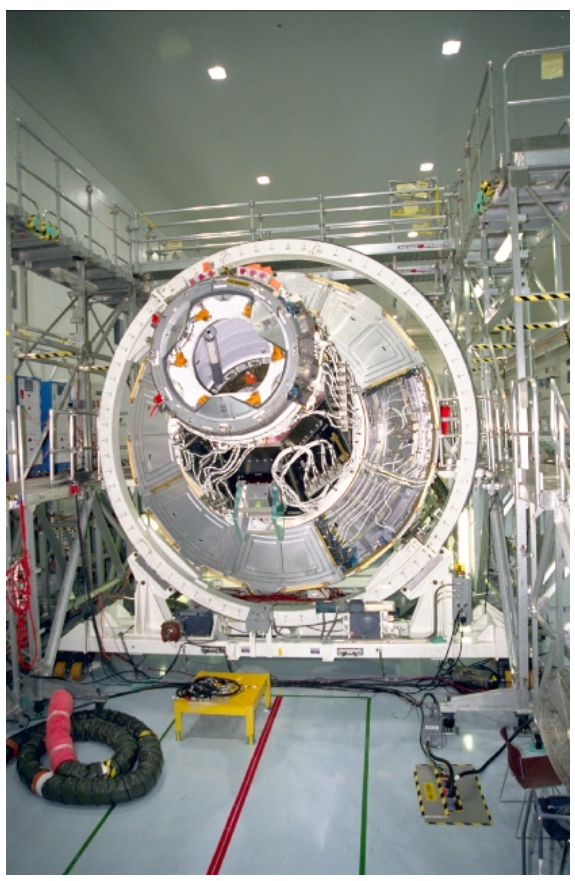

PMA 1 Attached to Node 1
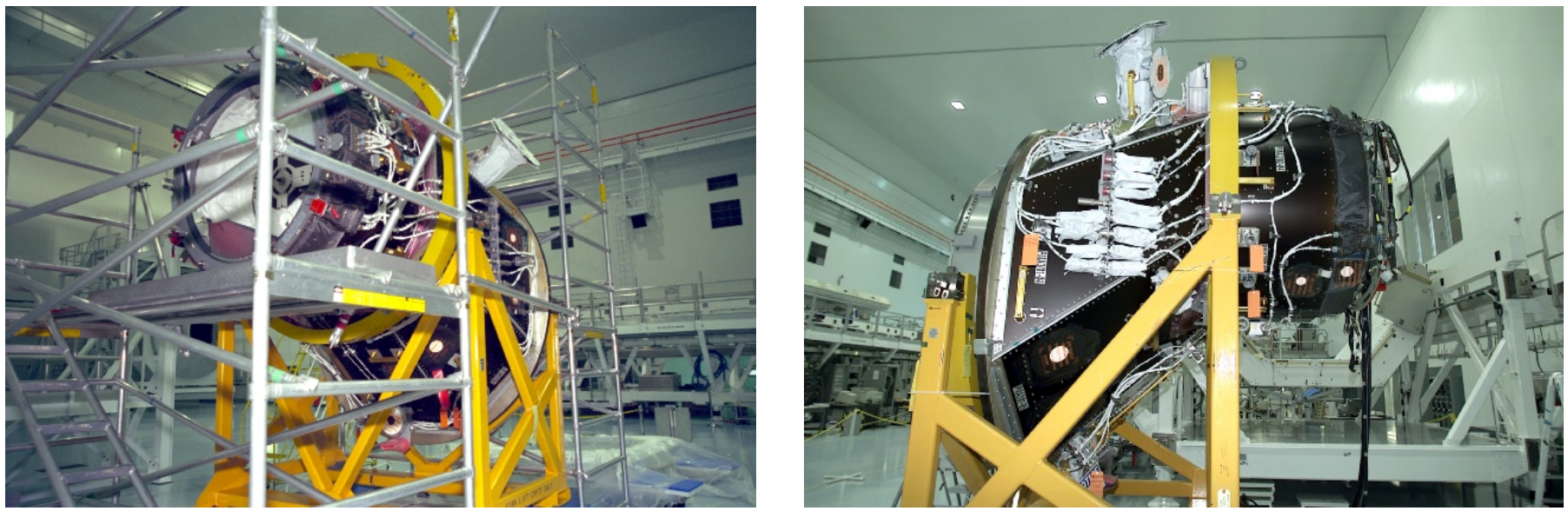

PMA 3 in the Test Stands at KSC

Figure 4 - PMAs during Processing at KSC 
CBM controller, when it is installed.

PMA 2/3 ACS:

The purpose of the PMA 2/3 ACS subsystem is to transfer high pressure oxygen and nitrogen from the Space Shuttle to the attached ISS Module, as shown in Figure 5. The high pressure oxygen and nitrogen is then routed within the ISS to the Airlock high pressure oxygen and nitrogen tanks via dedicated lines to refill the Airlock tanks with the Space Shuttle's excess oxygen and nitrogen. The PMA 2/3 high pressure oxygen and nitrogen distribution consists of quick disconnects (QDs), hard lines, flexible hoses, and Gamah fittings.

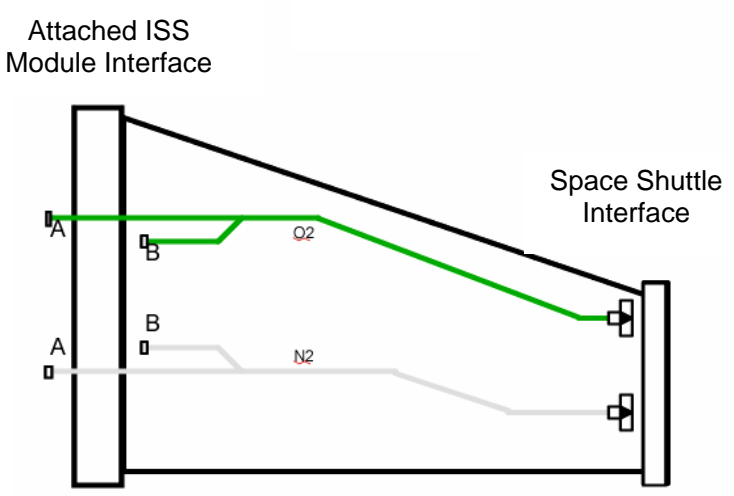

Figure 5 - PMA 2/3 ACS Schematic

\section{PMA 2/3 WRM:}

The purpose of the PMA 2/3 WRM subsystem is to support the transfer of Space Shuttle excess fuel cell water to ISS via a Space Shuttle provided flexible hose. The PMA 2/3 WRM consists only of velcro straps to restrain the Space Shuttle provided flexible hose when fuel cell water is being transferred from the Space Shuttle to the ISS Fuel Cell Water Rack, which is a scarred capability on ISS, via the Fuel Cell Water distribution.

\section{ELEMENT LEVEL VERIFICATION PROGRAM}

\section{PMA 1 THC QUALIFICATION METHODOLOGY:}

\begin{tabular}{|c|c|}
\hline Requirement & Verification \\
\hline $\begin{array}{l}\text { The PMA } 1 \text { shall } \\
\text { exchange intermodule } \\
\text { atmosphere with adjacent } \\
\text { ISS pressurized elements } \\
\text { in accordance with SSP } \\
\text { 42122, paragraph } 3.2 .2 .3 \text {, } \\
\text { and SSP } 42121 \text {, } \\
\text { paragraphs } 3.2 .1 .3 .1 \text { and } \\
3.2 .1 .3 .2 \text {. }\end{array}$ & $\begin{array}{l}\text { The PMA } 1 \text { capability to exchange } \\
\text { intermodule ventilation flow shall be } \\
\text { verified by analysis. An analysis shall be } \\
\text { performed to verify pressure drop } \\
\text { characteristics of the Intermodule } \\
\text { Ventilation (IMV) flow exchange between } \\
\text { the RS and USOS pressurized module in } \\
\text { accordance with the specified ICDs. } \\
\text { Further, the analysis shall include those } \\
\text { time periods when the crew enters the } \\
\text { PMA } 1 \text { prior to ingress into the station }\end{array}$ \\
\hline
\end{tabular}

\begin{tabular}{|c|l|}
\hline $\begin{array}{c}\text { Requirement } \\
\text { (cont'd) }\end{array}$ & \multicolumn{1}{c|}{$\begin{array}{c}\text { Verification } \\
\text { (cont'd) }\end{array}$} \\
\hline & $\begin{array}{l}\text { and it shall verify that adequate } \\
\text { circulation will be provided to remove } \\
\text { cO2 generated by two crew persons for } \\
\text { up to 2 hours at nominal metabolic rate. }\end{array}$ \\
\hline
\end{tabular}

The requirement references two ISS Interface Control Documents (ICDs). The relevant requirements from those documents are as follows:

\begin{tabular}{|l|l|l|}
\hline $\begin{array}{c}\text { SSP 42121 } \\
\text { Interface } \\
\text { Parameters }\end{array}$ & \multicolumn{1}{|c|}{$\begin{array}{c}\text { From Russian } \\
\text { Segment }\end{array}$} & \multicolumn{1}{|c|}{$\begin{array}{c}\text { To Russian } \\
\text { Segment }\end{array}$} \\
\hline Temperature & $\begin{array}{l}65 \text { to } 824^{\circ} \mathrm{F}(18.3 \text { to } \\
\left.28^{\circ} \mathrm{C}\right)\end{array}$ & $\begin{array}{l}65 \text { to } 85^{\circ} \mathrm{F}(18.3 \text { to } \\
\left.29.4^{\circ} \mathrm{C}\right)\end{array}$ \\
\hline Flow & $\begin{array}{l}127 \text { to } 148 \mathrm{cfm}(60 \text { to } \\
70 \mathrm{l} / \mathrm{s})\end{array}$ & $\begin{array}{l}127 \mathrm{to} 148 \mathrm{cfm}(60 \text { to } \\
70 \mathrm{l} / \mathrm{s})\end{array}$ \\
\hline Dew Point & 40 to $57^{\circ} \mathrm{F}(4.4$ to & $\begin{array}{l}40 \mathrm{to} 60^{\circ} \mathrm{F}(4.4 \text { to } \\
\left.15.6^{\circ} \mathrm{C}\right)\end{array}$ \\
\hline Pressure Rise & $\left.13.9^{\circ} \mathrm{C}\right)$ & \multicolumn{1}{|c|}{$\mathrm{N} / \mathrm{A}$} \\
\hline
\end{tabular}

* - The upper value is the specified value but during negotiations with the Russians it was shown that the air will normally have a dew point less than or equal to $57.2^{\circ} \mathrm{F}\left(14^{\circ} \mathrm{C}\right)$ by analysis. This is required to prevent condensation in the Soyuz when it is docked to the FGB nadir docking port, as requested by the Russians.

\begin{tabular}{|c|c|c|}
\hline $\begin{array}{c}\text { SSP } 42122 \\
\text { Interface } \\
\text { Parameters }\end{array}$ & From Node 1 & To Node 1 \\
\hline Temperature & $\begin{array}{l}65 \text { to } 85^{\circ} \mathrm{F} \text { (18.3 to } \\
\left.29.4^{\circ} \mathrm{C}\right)\end{array}$ & $\begin{array}{l}65 \text { to } 85^{\circ} \mathrm{F}(18.3 \text { to } \\
\left.29.4^{\circ} \mathrm{C}\right)\end{array}$ \\
\hline Flow & $\begin{array}{l}127 \text { to } 148 \mathrm{cfm}(60 \text { to } \\
70 \mathrm{l} / \mathrm{s})\end{array}$ & $\begin{array}{l}127 \text { to } 148 \mathrm{cfm} \text { (60 to } \\
70 \mathrm{l} / \mathrm{s})\end{array}$ \\
\hline Dew Point & $\begin{array}{l}40 \text { to } 60^{\circ} \mathrm{F}(4.4 \text { to } \\
\left.15.6^{\circ} \mathrm{C}\right)\end{array}$ & $\begin{array}{l}40 \text { to } 60^{\circ} \mathrm{F}(4.4 \text { to } \\
\left.15.6^{\circ} \mathrm{C}\right)\end{array}$ \\
\hline $\begin{array}{l}\text { PMA } 1 \text { Duct } \\
\text { Pressure Loss }\end{array}$ & $\mathrm{N} / \mathrm{A}$ & $\begin{array}{l}\leq 0.15 \mathrm{in}-\mathrm{H} 20 \text { at } 135 \\
\mathrm{cfm}(3.81 \mathrm{~mm}-\mathrm{H} 2 \mathrm{O} \text { at } \\
63.8 \mathrm{l} / \mathrm{s})\end{array}$ \\
\hline
\end{tabular}

For the analysis Boeing - Huntington Beach looked at five different IMV configurations. The first configuration consisted of having the Russian FGB flexible drag through air duct connected to the PMA 1 air duct assembly, the PMA 1 air register closed, the PMA 1 flexible air duct not connected to the Node 1 feedthrough, and the Russian supplied IMV air coming out into the PMA 1 volume from the end of the flexible duct. This configuration was analyzed in case the first ingress into PMA 1 was by the Increment 1 crew members after docking the Soyuz to the RS. The second configuration consisted of having the Russian FGB flexible drag through air duct connected to the PMA 1 air duct assembly, the PMA 1 air register closed, the PMA 1 flexible air duct connected to the Node 1 feedthrough and the Russian supplied IMV air routed through Node 1 into the aft end of the United States (U.S.) Laboratory Module with the air coming out of the U.S. Laboratory Module aft IMV diffuser. This configuration was analyzed as one of the two preplanned nominal IMV configurations. It was thought that this 
configuration would be used during the Assembly Sequence when the RS Vozdukh is providing $\mathrm{CO} 2$ control on ISS. The third configuration consisted of having the Russian FGB flexible drag through air duct disconnected from the PMA 1 air duct assembly, the PMA 1 air duct assembly capped at the FGB interface, the PMA 1 air register open, the PMA 1 flexible air duct connected to the Node 1 feedthrough and the PMA 1 air is coming out of the Node 1 port rack bay diffusers. This configuration was analyzed just in case the RS had to be isolated from the USOS and ventilation was required in PMA 1. The fourth configuration was similar to the third configuration except the cap on the PMA 1 duct assembly has been removed, the Russian FGB flexible drag through air duct is connected to the PMA 1 air duct assembly, and the PMA 1 air register is open. For the fourth configuration Boeing - Huntington Beach had to analyze the configuration to see if the Russian supplied IMV air would come out of the PMA 1 air register or would it come out the Node 1 port rack bay diffusers. The fifth and final configuration is the same as the fourth configuration except that the PMA 1 air register is closed forcing the Russian IMV supplied air out the Node 1 port rack bay diffusers. This configuration was analyzed as the other preplanned IMV configurations and was the one that the requirements addressed for the Assembly Complete (AC) configuration.

\section{$\underline{\text { Results: }}$}

The flow rates calculated for the five different configurations are as followed:

- First Configuration: $56.3 \mathrm{cfm}(26.5 \mathrm{l} / \mathrm{s})$

- Second Configuration: $122.8 \mathrm{cfm}(57.9 \mathrm{l} / \mathrm{s})$

- Third Configuration: $129.0 \mathrm{cfm}(60.8 \mathrm{l} / \mathrm{s})$

- Fourth Configuration: The Russian supplied IMV air was shown by analysis that it would come out the PMA 1 air register for flow rates below $180 \mathrm{cfm}(84.9 \mathrm{l} / \mathrm{s})$ and therefore is not a viable configuration

- Fifth Configuration: $137.7 \mathrm{cfm}(64.9 \mathrm{l} / \mathrm{s})$

These analysis results are very conservative and are based on component information provided by Boeing Huntsville, a ventilation development test that was performed at Huntington - Beach with no additional margin added to the duct pressure loss test values, and component specification data. For the components that went through a Component Qualification program the data from that process proved that the data used in the analysis was conservative.

Also, the calculated pressure loss for the PMA 1 air duct assembly at $135 \mathrm{cfm}$ was < 0.14 in $-\mathrm{H} 2 \mathrm{O}$ (3.55 $\mathrm{mm}-\mathrm{H} 2 \mathrm{O}$ ) for the second and the fifth THC configuration, as shown in the Flow Rate vs. Pressure Loss graph below.

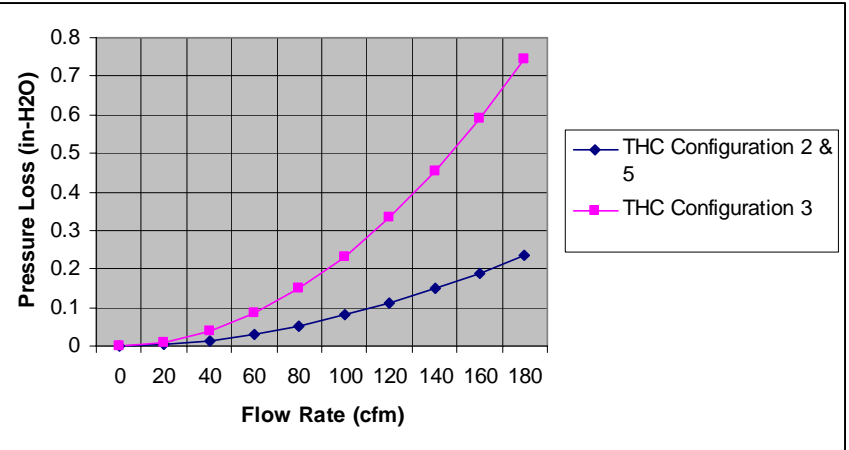

As for the air circulation requirement to support $\mathrm{CO} 2$ levels in the PMA 1 the analysis by Boeing - Huntington Beach using the first THC configuration showed that the partial pressure of carbon dioxide (ppCO2) increased above a steady state cabin level by $0.08 \mathrm{mmHg}$ in 1 minute, $0.34 \mathrm{mmHg}$ in 10 minutes, $0.36 \mathrm{mmHg}$ in 2 hours, and by $0.363 \mathrm{mmHg}$ if the THC configuration was held that way forever.

Therefore, the PMA 1 air duct assembly met all of its requirements for air exchange.

\section{PMA 2 THC QUALIFICATION METHODOLOGY:}

\begin{tabular}{|c|c|}
\hline Requirement & Verification \\
\hline $\begin{array}{l}\text { The PMA shall exchange } \\
\text { intermodule atmosphere } \\
\text { with adjacent ISS } \\
\text { pressurized elements in } \\
\text { accordance with SSP } \\
\text { 42097, paragraphs } \\
3.2 .2 .3 .2, \text { B3.2.2.3.2, } \\
\text { D3.2.2.3.2, and } \\
\text { E3.2.2.3.2. } \\
\text { The PMA shall exchange } \\
\text { intermodule ventilation } \\
\text { flow with the Orbiter in } \\
\text { accordance with NSTS } \\
\text { 21000-IDD-ISS, } \\
\text { paragraph S.6.4.4. }\end{array}$ & $\begin{array}{l}\text { The PMA capability to exchange } \\
\text { intermodule ventilation flow shall be } \\
\text { verified by analysis. An analysis shall be } \\
\text { performed to verify pressure drop } \\
\text { characteristics of the Intermodule } \\
\text { Ventilation (IMV) flow exchange between } \\
\text { the STS Orbiter and USOS pressurized } \\
\text { modules in accordance with the } \\
\text { applicable ICDs. Further, the analysis } \\
\text { shall include those time periods when the } \\
\text { crew enters the PMA prior to ingress into } \\
\text { the station and it shall verify that } \\
\text { adequate circulation will be provided to } \\
\text { remove CO2 generated by two } \\
\text { crewmembers for up to } 2 \text { hours at } \\
\text { nominal metabolic rate. The verification } \\
\text { is considered successful when the } \\
\text { analysis results indicates compliances } \\
\text { with the interface requirements in } \\
\text { accordance with the ICD for flow and } \\
\text { pressure and that the CO } 2 \text { levels remain } \\
\text { below } 10 \text { mmHg for two crewmembers for } \\
\text { up to } 2 \text { hours. }\end{array}$ \\
\hline
\end{tabular}

The requirement references four ISS ICDs and the Shuttle to ISS Interface Definition Document (IDD). The relevant requirements from those documents are as follows:

\begin{tabular}{|c|c|c|}
\hline $\begin{array}{l}\text { SSP } 42097 \\
\text { Interface } \\
\text { Parameters }\end{array}$ & $\begin{array}{c}\text { From Node } 2 \text { to } \\
\text { PMA } 2\end{array}$ & $\begin{array}{c}\text { To Node } 2 \text { from } \\
\text { PMA } 2\end{array}$ \\
\hline Temperature & $\begin{array}{l}65 \text { to } 85^{\circ} \mathrm{F}(18.3 \text { to } \\
\left.29.4^{\circ} \mathrm{C}\right)\end{array}$ & $\begin{array}{l}65 \text { to } 85^{\circ} \mathrm{F}(18.3 \text { to } \\
\left.29.4^{\circ} \mathrm{C}\right)\end{array}$ \\
\hline Flow & $\geq 125 \mathrm{cfm}(\geq 59 \mathrm{l} / \mathrm{s})$ & $\geq 125 \mathrm{cfm}(59 \mathrm{l} / \mathrm{s})$ \\
\hline $\begin{array}{l}\text { PMA } 2 \text { Duct } \\
\text { Pressure Loss }\end{array}$ & $\mathrm{N} / \mathrm{A}$ & $\begin{array}{l}0.23 \text { in }-\mathrm{H} 2 \mathrm{O}(5.84 \\
\mathrm{mm}-\mathrm{H} 2 \mathrm{O}) \text { when } \\
\text { Shuttle supplies } 69 \pm \\
5 \mathrm{cfm}(33 \pm 2 \mathrm{l} / \mathrm{s}) \text { of } \\
\text { air }\end{array}$ \\
\hline
\end{tabular}




\begin{tabular}{|c|c|c|}
\hline $\begin{array}{l}\text { SSP } 42097 \\
\text { Appendix B } \\
\text { Interface } \\
\text { Parameters }\end{array}$ & $\begin{array}{c}\text { From U.S. } \\
\text { Laboratory } \\
\text { Module to PMA } 2\end{array}$ & $\begin{array}{l}\text { To U.S. } \\
\text { Laboratory } \\
\text { Module from } \\
\text { PMA } 2\end{array}$ \\
\hline Temperature & $\begin{array}{l}65 \text { to } 85^{\circ} \mathrm{F} \text { (18.3 to } \\
\left.29.4^{\circ} \mathrm{C}\right)\end{array}$ & $\begin{array}{l}65 \text { to } 85^{\circ} \mathrm{F} \text { (18.3 to } \\
\left.29.4^{\circ} \mathrm{C}\right)\end{array}$ \\
\hline Flow & $\geq 140 \mathrm{cfm}(\geq 66 \mathrm{l} / \mathrm{s})$ & $\geq 140 \mathrm{cfm}(66 \mathrm{l} / \mathrm{s})$ \\
\hline $\begin{array}{l}\text { PMA } 2 \text { Duct } \\
\text { Pressure Loss }\end{array}$ & $\mathrm{N} / \mathrm{A}$ & $\begin{array}{l}0.28 \text { in }-\mathrm{H} 2 \mathrm{O}(7.11 \\
\mathrm{mm}-\mathrm{H} 2 \mathrm{O}) \text { when } \\
\text { Shuttle supplies } 69 \pm \\
5 \mathrm{cfm}(33 \pm 2 \mathrm{l} / \mathrm{s}) \text { of } \\
\text { air }\end{array}$ \\
\hline
\end{tabular}

\begin{tabular}{|l|c|l|}
\hline $\begin{array}{c}\text { SSP 42097 } \\
\text { Appendix D } \\
\text { Interface } \\
\text { Parameters }\end{array}$ & $\begin{array}{c}\text { From Node 1 to } \\
\text { PMA 3 }\end{array}$ & $\begin{array}{c}\text { To Node 1 from } \\
\text { PMA 3 }\end{array}$ \\
\hline Temperature & $\begin{array}{l}65 \text { to } 85^{\circ} \mathrm{F}(18.3 \text { to } \\
\left.29.4^{\circ} \mathrm{C}\right)\end{array}$ & $\begin{array}{l}65 \text { to } 85^{\circ} \mathrm{F}(18.3 \text { to } \\
\left.29.4^{\circ} \mathrm{C}\right)\end{array}$ \\
\hline Flow & \multicolumn{1}{|c|}{$\mathrm{N} / \mathrm{A}$} & $120 \mathrm{cfm}(57 \mathrm{l} / \mathrm{s})$ \\
\hline $\begin{array}{l}\text { PMA 3 Duct } \\
\text { Pressure Loss }\end{array}$ & $\mathrm{N} / \mathrm{A}$ & $\begin{array}{l}\leq 0.32 \mathrm{in}-\mathrm{H} 2 \mathrm{O}(8.13 \\
\mathrm{mm}-\mathrm{H} 2 \mathrm{O})\end{array}$ \\
\hline
\end{tabular}

\begin{tabular}{|l|l|l|}
\hline $\begin{array}{c}\text { SSP 42097 } \\
\text { Appendix E } \\
\text { Interface } \\
\text { Parameters }\end{array}$ & \multicolumn{1}{|c|}{$\begin{array}{c}\text { From Node 3 to } \\
\text { PMA 3 }\end{array}$} & \multicolumn{1}{c|}{$\begin{array}{c}\text { To Node 3 from } \\
\text { PMA 3 }\end{array}$} \\
\hline Temperature & $\begin{array}{l}65 \text { to } 85^{\circ} \mathrm{F}(18.3 \text { to } \\
\left.29.4^{\circ} \mathrm{C}\right)\end{array}$ & $\begin{array}{l}65 \text { to } 85^{\circ} \mathrm{F}(18.3 \text { to } \\
\left.29.4^{\circ} \mathrm{C}\right)\end{array}$ \\
\hline Flow & $\geq 125 \mathrm{cfm}(\geq 59 \mathrm{l} / \mathrm{s})$ & $\geq 130 \mathrm{cfm}(61 \mathrm{l} / \mathrm{s})$ \\
\hline $\begin{array}{l}\text { PMA 3 Duct } \\
\text { Pressure Loss }\end{array}$ & N/A & $\begin{array}{l}\leq 0.23 \mathrm{in}-\mathrm{H} 2 \mathrm{O}(5.84 \\
\text { mm }-\mathrm{H} 2 \mathrm{O}) \text { when } \\
\text { Shuttle supplies } 69 \pm \\
5 \mathrm{cfm}(33 \pm 2 \mathrm{l} / \mathrm{s}) \text { of } \\
\text { air }\end{array}$ \\
& & \\
\hline
\end{tabular}

\begin{tabular}{|l|c|c|}
\hline $\begin{array}{c}\text { NSTS-21000- } \\
\text { IDD-ISS } \\
\text { Interface } \\
\text { Parameters }\end{array}$ & $\begin{array}{c}\text { From Space } \\
\text { Shuttle to } \\
\text { PMA 2/3 }\end{array}$ & $\begin{array}{c}\text { To Space Shuttle } \\
\text { from PMA 2/3 }\end{array}$ \\
\hline Temperature & 55 to $85^{\circ} \mathrm{F}(12.7$ to & $\begin{array}{l}65 \text { to } 85^{\circ} \mathrm{F}(18.3 \text { to } \\
\left.29.4^{\circ} \mathrm{C}\right)\end{array}$ \\
\hline Dew Point & $\left.29.4^{\circ} \mathrm{C}\right)$ & $\begin{array}{l}40 \text { to } 60^{\circ} \mathrm{F}(4.4 \text { to } \\
\left.15.6^{\circ} \mathrm{C}\right)\end{array}$ \\
\hline Flow & $39{\text { to } 61^{\circ} \mathrm{F}(3.9 \text { to }}^{\left.16.1^{\circ} \mathrm{C}\right)}$ & \multicolumn{2}{|c|}{$\mathrm{N} / \mathrm{A}$} \\
\multicolumn{2}{|c|}{ see Flow Rate vs. } \\
\hline
\end{tabular}

** - Space Shuttle provided ODS Booster Fan interface verification data. Better interface data was provided after the verification was closed and is documented in NSTS-21000-IDD-ISS. This graph is more conservative than the data that was provided later by the Space Shuttle.

For the analysis Boeing - Huntington Beach looked at four different IMV configurations. The first configuration consisted of having the Space Shuttle provide IMV air to PMA 2/3, the PMA 2/3 air register closed, the PMA 2/3 flexible air duct not connected to the attached ISS pressurized module feedthrough, and the Space Shuttle

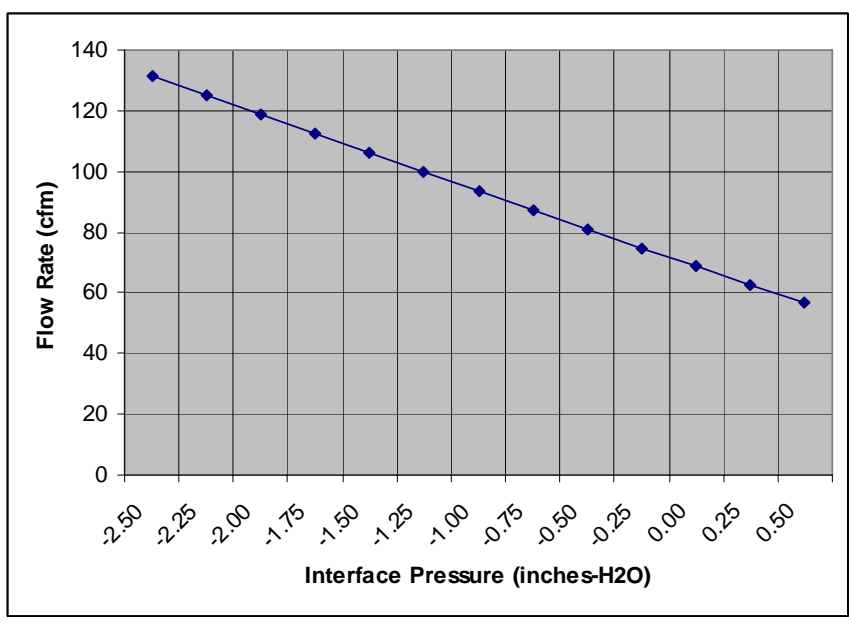

supplied IMV air coming out into the PMA 2/3 volume from the end of the flexible duct. This configuration was analyzed to support the first ingress into PMA 2/3 from the Space Shuttle. The second configuration consisted of having the Space Shuttle provide IMV air to PMA 2/3, the PMA 2/3 air register closed, the PMA 2/3 flexible air duct connected to the attached ISS pressurized module feedthrough and the Space Shuttle supplied IMV air routed to the attached ISS pressurized module. This configuration was analyzed as one of the nominal preplanned IMV configuration and was the one that the requirements for Node 1 to PMA 3 addressed. The third configuration consisted of having no Space Shuttle provided IMV air to PMA 2/3, the PMA 2/3 air duct assembly capped at the Space Shuttle interface, the PMA 2/3 air register open, the PMA 2/3 flexible air duct connected to the attached ISS pressurized module feedthrough and the PMA 2/3 air coming out into the attached ISS pressurized module. This configuration was analyzed to support ingress into PMA 2/3 when the Space Shuttle is not present. The fourth and final configuration consisted of having Space Shuttle provide IMV air to PMA 2/3, the PMA 2/3 air register open, the PMA 2/3 flexible air duct connected to the attached ISS pressurized module feedthrough and the IMV air is coming out into the attached ISS pressurized module. This configuration was analyzed as the other possible nominal IMV configuration and is the one that the requirements addressed except for the Node 1 to PMA 3 interface.

\section{$\underline{\text { Results: }}$}

The calculated results are as follows:

- First Configuration: Calculated flow rate out of the PMA $2 / 3$ ducting was $65.6 \mathrm{cfm}(31.0 \mathrm{l} / \mathrm{s})$

- Second Configuration: The PMA 3 pressure drop for Node 1 interface is 0.319 in - $\mathrm{H} 2 \mathrm{O}$ (8.1 $\mathrm{mm}-\mathrm{H} 2 \mathrm{O}$ ) at $120 \mathrm{cfm}(57 \mathrm{l} / \mathrm{s})$, as shown in the Pressure Loss vs. Flow Rate graph below 
- Third Configuration: No results were discussed in the Verification Report but the Pressure Loss vs. Flow Rate data was provided in the graph below

- Fourth Configuration: The results are as shown in the Table below for U.S. Laboratory Module, Node 2, and Node 3 interfaces and in the graph below

\begin{tabular}{|c|c|c|c|}
\hline $\begin{array}{l}\text { PMA 2/3 } \\
\text { Interface }\end{array}$ & $\begin{array}{c}\text { Assumed } \\
\text { Flow Rate } \\
\text { from PMA } \\
2 / 3\end{array}$ & $\begin{array}{c}\text { Calculated } \\
\text { Orbiter Flow } \\
\text { Rate }\end{array}$ & $\begin{array}{c}\text { Calculated } \\
\text { PMA 2/3 } \\
\text { Pressure } \\
\text { Drop }\end{array}$ \\
\hline $\begin{array}{l}\text { PMA } 2 \text { to } \\
\text { Node } 2\end{array}$ & $\begin{array}{l}125 \mathrm{cfm}(59 \\
\mathrm{l} / \mathrm{s})\end{array}$ & $\begin{array}{l}68.4 \mathrm{cfm}(32.3 \\
\mathrm{l} / \mathrm{s})\end{array}$ & $\begin{array}{l}0.205 \text { in - } \mathrm{H} 2 \mathrm{O} \\
(5.2 \mathrm{~mm}- \\
\mathrm{H} 2 \mathrm{O})\end{array}$ \\
\hline $\begin{array}{l}\text { PMA } 2 \text { to U.S. } \\
\text { Laboratory } \\
\text { Module }\end{array}$ & $\begin{array}{l}140 \mathrm{cfm}(66 \\
\mathrm{I} / \mathrm{s})\end{array}$ & $\begin{array}{l}69.1 \mathrm{cfm}(32.6 \\
\mathrm{l} / \mathrm{s})\end{array}$ & $\begin{array}{l}0.241 \mathrm{in} \mathrm{-} \mathrm{H} 2 \mathrm{O} \\
(6.1 \mathrm{~mm}- \\
\mathrm{H} 2 \mathrm{O})\end{array}$ \\
\hline $\begin{array}{l}\text { PMA } 3 \text { to } \\
\text { Node } 3\end{array}$ & $130 \mathrm{cfm}(61 \mathrm{l} / \mathrm{s})$ & $\begin{array}{l}68.6 \mathrm{cfm}(32.4 \\
\mathrm{l} / \mathrm{s})\end{array}$ & $\begin{array}{l}0.217 \mathrm{in}-\mathrm{H} 2 \mathrm{O} \\
(5.5 \mathrm{~mm}- \\
\mathrm{H} 2 \mathrm{O})\end{array}$ \\
\hline
\end{tabular}
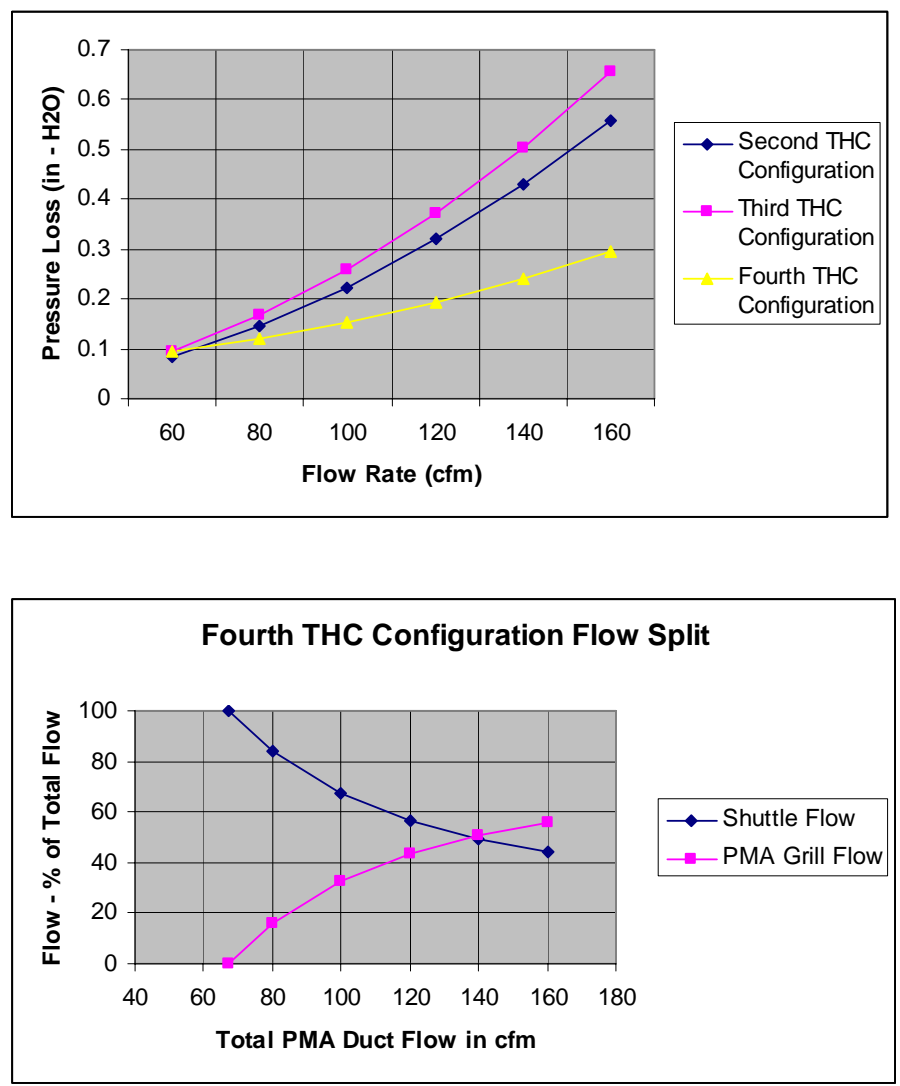

As for the air circulation requirement to support $\mathrm{CO} 2$ levels in the PMA $2 / 3$ the analysis by Boeing Huntington Beach using the first THC configuration showed that the partial pressure of carbon dioxide (ppCO2) increased above a steady state cabin level by $0.083 \mathrm{mmHg}$ in 1 minute, $0.296 \mathrm{mmHg}$ in 10 minutes, $0.310 \mathrm{mmHg}$ in 2 hours, and by $0.310 \mathrm{mmHg}$ if the THC configuration was held that way forever. met all of the requirements for air exchange.

The Verification Report also provided additional information for the PMA 3 to Node 1 extension duct. The extension duct allows the normal PMA 3 duct to reach the desired Node 1 IMV feedthrough. The PMA 3 -63 inch $(160 \mathrm{~cm})$ extension duct had a pressure loss of $0.134 \mathrm{in}-\mathrm{H} 2 \mathrm{O}(3.4 \mathrm{~mm}-\mathrm{H} 2 \mathrm{O})$ at $120 \mathrm{cfm}(57 \mathrm{l} / \mathrm{s})$.

\section{PMA 2/3 ACS QUALIFICATION METHODOLOGY:}

\section{High-Pressure Nitrogen:}

\begin{tabular}{|c|c|}
\hline Requirement & Verification \\
\hline $\begin{array}{l}\text { PMA shall deliver } \\
\text { recharge nitrogen to the } \\
\text { adjacent ISS pressurized } \\
\text { element at the pressure, } \\
\text { temperature, and up to } \\
\text { the flow rate as specified } \\
\text { in SSP } 42097, \\
\text { paragraphs } 3.2 .2 .3 .3 .5 \text {, } \\
\text { B3.2.2.3.4, and } \\
\text { E3.2.2.3.5. } \\
\text { The PMA shall receive } \\
\text { recharge nitrogen from } \\
\text { the Orbiter in accordance } \\
\text { with NSTS } 21000-\text { IDD- } \\
\text { ISS, paragraph S.6.4.3.2. }\end{array}$ & $\begin{array}{l}\text { The PMA capability to receive recharge } \\
\text { nitrogen from STS and deliver it to the } \\
\text { adjacent ISS element shall be verified by } \\
\text { analysis and inspection. An analysis } \\
\text { shall be done to verify the interface } \\
\text { conditions are met in the design of the } \\
\text { distribution plumbing in accordance with } \\
\text { applicable ICDs. Inspection of the } \\
\text { drawings and layouts shall be conducted } \\
\text { to account for plumbing and interface } \\
\text { connections to the adjacent distribution } \\
\text { lines. } \\
\text { The verification is considered successful } \\
\text { when the results of the analysis indicates } \\
\text { compliance with the interface } \\
\text { requirements as specified in SSP } 42097 \\
\text { and NSTS 21000-IDD-ISS, paragraph } \\
\text { S.6.4.3.2, and the inspection will indicate } \\
\text { full compliance for all distribution } \\
\text { hardware. }\end{array}$ \\
\hline
\end{tabular}

The requirement references three ISS ICDs and the Shuttle to ISS Interface Definition Document (IDD). The relevant requirements from those documents are as follows:

\begin{tabular}{|c|c|l|}
\hline $\begin{array}{c}\text { SSP 42097 } \\
\text { (Appendix B, } \\
\begin{array}{c}\text { Appendix E) } \\
\text { Interface } \\
\text { Parameters }\end{array}\end{array}$ & $\begin{array}{c}\text { From Node 2 } \\
\text { (U.S. Laboratory } \\
\text { Module, Node 3) } \\
\text { to PMA 2/3 }\end{array}$ & $\begin{array}{c}\text { To Node 2 (U.S. } \\
\text { Laboratory } \\
\text { Module, Node 3) } \\
\text { from PMA 2/3 }\end{array}$ \\
\hline Temperature & N/A & $\begin{array}{l}25 \text { to } 113^{\circ} \mathrm{F}(-3.9 \text { to } \\
\left.45^{\circ} \mathrm{C}\right)\end{array}$ \\
\hline Flow Rate & N/A & $\begin{array}{l}\leq 3 \mathrm{lbm} / \mathrm{hr}(\leq 1.4 \\
\mathrm{kg} / \mathrm{hr})\end{array}$ \\
\hline Maximum Pressure & N/A & $3400 \mathrm{psia}(23.4 \mathrm{MPa})$ \\
\hline
\end{tabular}

\begin{tabular}{|c|c|c|}
\hline $\begin{array}{l}\text { NSTS-21000- } \\
\text { IDD-ISS } \\
\text { Interface } \\
\text { Parameters }\end{array}$ & $\begin{array}{c}\text { From Space } \\
\text { Shuttle to } \\
\text { PMA 2/3 }\end{array}$ & $\begin{array}{l}\text { To Space Shuttle } \\
\text { from PMA } 2 / 3\end{array}$ \\
\hline Temperature & $\begin{array}{l}25 \text { to } 113^{\circ} \mathrm{F}(-3.9 \text { to } \\
\left.45^{\circ} \mathrm{C}\right)\end{array}$ & N/A \\
\hline 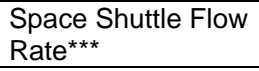 & $\begin{array}{l}\leq 32.5 \mathrm{lbm} / \mathrm{hr}(\leq 14.7 \\
\mathrm{kg} / \mathrm{hr})\end{array}$ & N/A \\
\hline $\begin{array}{l}\text { Space Shuttle } \\
\text { Maximum Pressure }\end{array}$ & 3300 psia (22.7 MPa) & N/A \\
\hline
\end{tabular}


For the analysis Boeing - Huntington Beach analyzed the pressure loss for the longer of the two possible paths at the conditions called in the ISS ICDs.

\section{$\underline{\text { Results: }}$}

The calculated pressure loss for the PMA 2/3 Nitrogen Recharge subsystem was 0.017 psid $(0.117 \mathrm{kPa}$ differential) with an additional $10 \%$ margin added to the calculated results. The analysis results for this subsystem is very conservative and is based on flex hose information provided by Boeing - Huntsville and QD pressure drop information provided by the QD supplier. The QD also went through a Component Qualification program and the data from that process proved that the data initially supplied by the QD supplier and used in the analysis was conservative.

The requirement for this subsystem did not have any pressure loss pass/fail requirement but the value was very low and it was agreed based on that fact that the analysis part of the Verification was acceptable.

The inspection memorandum for PMA 2/3 also showed that the drawing called out in the memorandum met the inspection part of the Verification.

\section{High-Pressure Oxygen:}

\section{Requirement}

\section{PMA shall deliver} recharge oxygen to the adjacent ISS pressurized element at the pressure, temperature, and up to flow rate as specified in SSP 42097, paragraphs 3.2.2.3.3.4, B3.2.2.3.3, and E3.2.2.3.4.

The PMA shall receive recharge oxygen from the Orbiter in accordance with NSTS 21000-IDD-ISS, paragraph S.6.4.3.1.

\section{Verification} The PMA capability to receive recharge oxygen from STS and deliver it to the adjacent ISS element shall be verified by analysis and inspection. An analysis shall be done to verify the interface conditions (specified in ICD) are met in the design of the distribution plumbing. Inspection of the drawings and layouts shall be conducted to account for plumbing and interface connections to the adjacent distribution lines.

The verification is considered successful when the results of the analysis indicates compliance with the interface requirements as specified in SSP 42097 and NSTS 21000-IDD-ISS, paragraph S.6.4.3.1, and the inspection will indicate full compliance for all distribution hardware.
The requirement references three ISS ICDs and the Shuttle to ISS Interface Definition Document (IDD). The relevant requirements from those documents are as follows:

\begin{tabular}{|c|c|c|}
\hline $\begin{array}{c}\text { SSP 42097 } \\
\text { (Appendix B, } \\
\begin{array}{c}\text { Appendix E) } \\
\text { Interface } \\
\text { Parameters }\end{array}\end{array}$ & $\begin{array}{c}\text { From Node 2 } \\
\text { (U.S. Laboratory } \\
\text { Module, Node 3) } \\
\text { to PMA 2/3 }\end{array}$ & $\begin{array}{c}\text { To Node 2 (U.S. } \\
\text { Laboratory, } \\
\text { Node 3) from } \\
\text { PMA 2/3 }\end{array}$ \\
\hline Temperature & N/A & $\begin{array}{l}25 \text { to } 113^{\circ} \mathrm{F}(-3.9 \text { to } \\
\left.45^{\circ} \mathrm{C}\right)\end{array}$ \\
\hline Flow Rate & N/A & $\begin{array}{l}\leq 16 \mathrm{lbm} / \mathrm{hr}(\leq 7.3 \\
\mathrm{kg} / \mathrm{hr})\end{array}$ \\
\hline Maximum Pressure & $\mathrm{N} / \mathrm{A}$ & $1050 \mathrm{psia}(7.2 \mathrm{MPa})$ \\
\hline
\end{tabular}

\begin{tabular}{|l|c|c|}
\hline $\begin{array}{c}\text { NSTS-21000- } \\
\text { IDD-ISS } \\
\text { Interface } \\
\text { Parameters }\end{array}$ & $\begin{array}{c}\text { From Space } \\
\text { Shuttle to } \\
\text { PMA 2/3 }\end{array}$ & $\begin{array}{c}\text { To Space Shuttle } \\
\text { from PMA 2/3 }\end{array}$ \\
\hline Temperature & $\begin{array}{l}33 \text { to } 113^{\circ} \mathrm{F}(0.6 \text { to } \\
\left.45^{\circ} \mathrm{C}\right)\end{array}$ & N/A \\
\hline $\begin{array}{l}\text { Space Shuttle Flow } \\
\text { Rate }\end{array}$ & $\mathrm{kg} / \mathrm{hr})$ & $\mathrm{N} / \mathrm{Am} / \mathrm{hr}(\leq 22.7$ \\
\hline $\begin{array}{l}\text { Space Shuttle } \\
\text { Maximum Pressure }\end{array}$ & $1050 \mathrm{psia}(7.2 \mathrm{MPa})$ & $\mathrm{N} / \mathrm{A}$ \\
*** - The flow rate is restricted by the ISS recharge distribution \\
subsystem
\end{tabular}

For the analysis Boeing - Huntington Beach analyzed the pressure loss for the longer of the two possible paths at the conditions called in the ISS ICDs.

\section{$\underline{\text { Results: }}$}

The calculated pressure loss for the PMA 2/3 Oxygen Recharge subsystem was 0.67 psid (4.62 kPa differential) with an additional $10 \%$ margin added to the calculated results. The analysis results for this subsystem is very conservative and is based on flex hose information provided by Boeing - Huntsville and QD pressure drop information provided by the QD supplier. The QD also went through a Component Qualification program and the data from that process proved that the data initially supplied by the QD supplier and used in the analysis was conservative.

The requirement for this subsystem did not have any pressure loss pass/fail requirement but the value was very low and it was agreed based on that fact that the analysis part of the Verification was acceptable.

The inspection memorandum for PMA 2/3 also showed that the drawing called out in the memorandum met the inspection part of the Verification.

\section{PMA 2/3 WRM QUALIFICATION METHODOLOGY:}

\begin{tabular}{|c|c|}
\hline Requirement & Verification \\
\hline $\begin{array}{l}\text { The PMA shall provide } \\
\text { installation provisions } \\
\text { (clamps, tie-down, etc.) to } \\
\text { secure the Space } \\
\text { Transportation System } \\
\text { (STS) provided flexible } \\
\text { hose for transfer of STS } \\
\text { fuel cell water to ISS } \\
\text { pressurized elements in } \\
\text { accordance with SSP } \\
\text { 42097, paragraph } \\
\text { 3.2.2.3.3. }\end{array}$ & $\begin{array}{l}\text { This PMA capability to accommodate fuel } \\
\text { cell water transfer hose shall be verified } \\
\text { by inspection and analysis. An } \\
\text { inspection of the drawings shall be } \\
\text { performed to verify the locations of } \\
\text { installation provisions. An analysis shall } \\
\text { be performed to verify the design of the } \\
\text { installation provisions will be compatible } \\
\text { with transfer of fuel cell water in } \\
\text { accordance with the specified ICD. } \\
\text { The verification shall be considered } \\
\text { successful when the results of the } \\
\text { inspection and analysis indicate that fuel } \\
\text { cell water transfer hose can be secured } \\
\text { in place during water transfer hose can } \\
\text { be secured in place during water transfer } \\
\text { at specified condition. }\end{array}$ \\
\hline
\end{tabular}

\section{$\underline{\text { Results: }}$}

Since the Space Shuttle provided fuel cell water transfer hose for PMA 2/3 was deferred until later in the 
Assembly Sequence after the delivery of the ISS fuel cell rack it was decided that the analysis Verification by the Space Shuttle Program was not required until later. Since then the fuel cell water rack has been cancelled and the analysis Verification is not required. Boeing Huntington Beach did show in the inspection memorandum for PMA 2/3 that the drawing called out in the memorandum did meet the inspection part of the Verification.

\section{CONCLUSION}

The Verification of the PMAs utilized a building block approach from the Component Qualification data through to the Element Level Verification. This paper provides a general overview of the ISS ECLS subsystems in the PMAs and of the ISS ECLS Element Level Verification program. It also showed that the PMAs met the ISS ECLS Element Level requirements.

\section{REFERENCES}

1. "Prime Item Development Specification for the Pressurized Mating Adapter"; SP-M-301, Revision L plus SCN 071; August 24, 2004.

2. "Addendum Specification for Pressurized Mating Adapter - 1 (PMA - 1)"; S684-10115, Revision $\mathrm{H}$; August 30, 2002.

3. "U.S. On-Orbit Segment Pressurized Mating Adapter-1 to Russian Segment FGB Interface Control Document, Part 1"; SSP 42121, Revision B; December 15, 1998.

4. "Resource Node 1 to Pressurized Mating Adapter-1 Interface Control Document, Part 1"; SSP 42122, Revision D plus IRNs, 0019, 0016, and 0020; December 20, 2002.

5. "Space Station Program Pressurized Mating Adapter 2 \& 3 to U.S. Pressurized Elements Core (Node 2 to PMA 2) Interface Control Document, Part 1"; SSP 42097, Revision D, December 31, 2002.

6. "Pressurized Mating Adapter 2 \& 3 to United States Pressurized Elements (USL to PMA-2) Interface Control Document, Part 1, Appendix B"; SSP 42097, Revision E, June 30, 2006.

7. "Pressurized Mating Adapter 2 \& 3 to United States Pressurized Elements (Node 1 to PMA-3) Interface Control Document, Part 1, Appendix D"; SSP 42097, Revision E, June 30, 2006.

8. "Space Station Program Pressurized Mating Adapter 2 \& 3 to United States Pressurized Elements (Node Element 3 to Pressurized Mating Adapter 3) Interface Control Document, Part 1, Appendix E"; SSP 42097, Revision E, June 18, 2004.

9. "International Space Station Interface Definition Document"; NSTS-21000-IDD-ISS; Revision A; February 18, 1998.
10. Boeing - Huntington Beach; "International Space Station Pressurized Mating Adapter 1 ECLSS Verification Analysis Report"; MDC 97H0377B; January 30, 1988.

11. Boeing - Huntington Beach; "International Space Station Pressurized Mating Adapter 2/3 ECLSS Verification Analysis Report"; MDC 96H0616B; January 30, 1988.

12. "Fluids Drawing Inspections for PMA Requirements" Memorandum; A3-J071 DR-M9800382; March 2, 1998.

13. Erwin, Lowell; Email titled "Evaluation of Shuttle IMV Supply"; March 4, 1998.

\section{CONTACT}

David E. Williams

NASA, Lyndon B. Johnson Space Center /

Mail Stop: EC6

2101 NASA Parkway

Houston, TX 77058

\section{ACRONYMS}

${ }^{\circ} \mathrm{C}: \quad$ degree celsius

${ }^{\circ} \mathrm{F}$ : degree fahrenheit

AC: Assembly Complete

ACS: Atmosphere Control and Supply

APAS: Androgynous Peripheral Attachment System

CBM: Common Berthing Mechanism

cfm: cubic feet per minute

$\mathrm{cm}$ : centimeter

CO2: carbon dioxide

ECLS: Environmental Control and Life Support

FGB: Functional Cargo Block (Russian to English Translation)

$\mathrm{H} 2 \mathrm{O}$ : water

hr: hour

ICD: Interface Control Document

IDD: Interface Definition Document

IMV: Intermodule Ventilation

in: inch

ISS: International Space Station

kg: kilogram

$\mathrm{kPa}$ : kilopascal

KSC: Kennedy Space Center

$\mathrm{lbm}$ : pound mass

I/s: liter per second

MDM: Multiplexer/Demultiplexer

$\mathrm{mm}$ : millimeter

$\mathrm{mmHg}$ : millimeter of mercury

MPa: megapascal

NSTS: National Space Transportation System

ODS: Orbiter Docking System

PIDS: Prime Item Development Specification

PMA: Pressurized Mating Adapter

psia: pounds per square inch absolute

psid: pounds per square inch differential

QD: Quick Disconnect 
RS: Russian Segment

SSP: $\quad$ Space Station Program

THC: Temperature and Humidity Control

U.S.: United States

USOS: United States On-Orbit Segment

WRM: Water Recovery and Management 